\title{
Pengaruh Intensitas Menonton Program Youtube Channel Wirda Mansur terhadap Motivasi Membaca Al-Qur'an Subscriber
}

\author{
Nur Adilla Maulina*, Nandang HMZ \\ Bandung, Indonesia. \\ *adillamaulina7@gmail.com, ninianteh58@gmail.com
}

Prodi Komunikasi dan Penyiaran Islan, Fakultas Dakwah, Universitas Islam

\begin{abstract}
The existence of mass media is very influential in everyday life. One of them is youtube. Youtube is a social media platform which provides various kinds of video content that is easy to access. Currently, there are many content creators who use YouTube as a medium for preaching, one of which is Wirda Mansur. There are so many youtube shows that motivate users or subscribers. This study focused on the effect of the intensity of watching YouTube on the motivation to read the Qur'an. Based on the description above, the problems in this research are formulated as follows: (1) How does the Youtube Chanel Wirda Mansur Program motivate in reading the Qur'an? (2) How is the intensity of watching Wirda Mansur's youtube channel program? (3) How does the intensity of watching Wirda Mansur's youtube channel program affect the motivation to read the Qur'an for subscribers? Researchers used quantitative methods. The population chosen in this study was Wirda Mansur's subscribers, which amounted to 1,042 million. With a $10 \%$ sampling technique the number of samples obtained was 110 respondents. The data collection technique used in this research is a questionnaire/ questionnaire. The analysis technique used in this research is descriptive. The results of this study are: the effect of watching intensity is influenced by motivation, activity duration, activity frequency, presentation, attitude and interest direction. The effect of the intensity of watching YouTube on the motivation to read the Qur'an is $14.20 \%$.
\end{abstract}

Keywords: Mass Media, Intensity, Motivation.

Abstrak. Keberadaan media massa sangat berpengaruh dalam kehidupan sehari-hari. Salah satunya adalah youtube. Youtube merupakan sebuah platform media sosial yang mana menyediakan berbagai macam content video yang mudah untuk diakses. Saat ini banyak sekali content creator yang memanfaatkan youtube sebagai media berdakwah salah satunya Wirda Mansur. Banyak sekali tayangan-tayangan youtube yang memotivasi para pengguna atau subscriber. Pada penelitian ini difokuskan terhadap pengaruh intensitas menonton youtube terhadap motivasi membaca Al-Qur'an. berdasarkan uraian diatas maka permasalahan dalam penelitian ini dirumuskan sebagai berikut: (1) Bagaimana Program Youtube Chanel Wirda Mansur memotivasi dalam membaca Al-Qur'an? (2) Bagaimana intensitas menonton program youtube chanel Wirda Mansur? (3) Bagaimana pengaruh intensitas menonyon program youtube chanel Wirda Mansur terhadap motivasi membaca Al-Qur'an subscriber? Peneliti menggunakan metode kuantitatif. Populasi yang dipilih dalam penelitian ini adalah subscriber Wirda Mansur yang berjumlah 1.042 juta. Dengan teknik pengambilan sampel $10 \%$ jumlah sampel yang diperoleh sebanyak 110 orang responden. Teknik pengambilan data yang digunakan dalam penelitian ini adalah angket/kuisioner. Adapun teknik analisis yang digunakan dalam penelitian ini adalah deskriptif. Hasil dari penelitian ini adalah: pengaruh intensitas menonton dipengaruhi oleh motivasi, durasi kegiatan, frekuensi kegiatan, presentasi, arah sikap dan minat. Pengaruh intensitas menonton youtube terhadap motivasi membaca Al-Qur'an adalah 14,20\%.

Kata Kunci: Media Massa, Intensitas, Motivasi. 


\section{A. Pendahuluan}

Komunikasi Massa adalah suatu proses dalam mana komunikator menggunakan media untuk menyebarkan pesan-pesan secara luas, dan secara terus menerus menciptakan makna-makna yang diharapkan dapat mempengaruhi khalayak yang besar dan berbeda-beda melalui berbagai cara. Menurut Janowitz komunikasi massa terdiri atas lembaga dan teknik dari kelompok tertentu yang menggunakan alat teknologi (pers, radio, film dan sebagainya) untuk menyebarkan konten simbolis kepada khalayak yang besar, heterogen dan sangat tersebar.

Media massa merupakan saluran yang digunakan oleh jurnalistik atau komunikasi massa. Tujuannya, memanfaatkan kemampuan teknik dari media tersebut, sehingga dapat mencapai khalayak dalam jumlah tak terhingga pada saat yang sama. Media massa dibagi menjadi dua menurut sifatnya, media massa tercetak dan media massa elektronik. Media massa merupakan saluran komunikasi yang memproduksi dan mendistribusikan berita, konten hiburan, visual art, dan produk budaya lainnya untuk sejumlah orang.Media massa adalah bagian dari sistem masyarakat dimana ia berkembang. Ia hanyalah organ dari suatu batang tubuh besar bernama negara. Tetapi, tentu saja selain sekedar menjadi bagian dari sistem, media massa juga bisa memberikan kontribusi yang cukup penting dalam mengkondisikan perubahan dalam suatu masyarakat.

Keberadaan media massa sangat berpengaruh dalam kehidupan sehari-hari. Media massa mampu mengubah perilaku masyarakat. Media massa bisa menjadi negatif ataupun positif tergantung dari intensitas penggunaan media massa. Menurut Ardianto dalam bukunya yang berjudul Komunikasi Massa, tingkat penggunaan media dapat dilihat dari frekuensi dan durasi dari penggunaan media tersebut. Dampak positif dari adanya media masa dapat menambah edukasi bagi masyarakat dengan adanya media massa kita merasakan bahwa berita yang didapat amat penting bagi kita dalam menjalankan tugas harian. Sedangkan dampak negatif tersebut dapat terlihat dari munculnya sifat candu terhadap media sosial yang bisa mengakibatkan naik dan turunnya semangat untuk menjalankan pelaksanaan shalat. Hal tersebut sesuai dengan penjelasan Bambang Syamsul Arifin bahwa mahasiswa yang tergolong remaja memiliki jiwa agama yang tidak stabil.

Kegiatan dakwah kian semarak ditandai tingginya respon sejumlah media. Dalam perkembanganya, media mampu melakukan konstruksi sosial dalam membentuk opini publik terhadap realitas di tengah-tengah masyarakat. Dengan demikian, mengukur positif dan negatifnya media terhadap perilaku masyarakat perlu kajian akademik sehingga memiliki kualifikasi keilmiahan. Tentu baik dan buruk dampak media sangat tergantung dari perspektif yang digunakan. Aktivitas dakwah menjadi keniscayaan dengan melakukan inovasi-inovasi dalam menjaga eksistensi agama secara berkesinambungan. Dalam hal ini, Islam sebagai agama dakwah (missionary religion) menjadikan kegiatan tersebut sebagai perekat terpeliharanya nilainilainya Islam.

Youtube merupakan sebuah platform media sosial yang didirikan oleh Chad Hurley, Steve Chen dan Jawed Karem di tahun 2005. Menurut penelitian yang dilakukan Wearesocial tahun 2019 menyebutkan 88\% masyarakat Indonesia aktif menggunakan Youtube. Saat ini, banyak sekali content creator yang memanfaatkan youtube sebagai media yang digunakan untuk berdakwah kepada masyarakat informasi, salah satunya yaitu Wirda Mansur. Wirda Mansur mengemas video dakwahnya dengan jenis yang beragam. Pada salah satu konten Youtubenya, Wirda mengatakan bahwa dia akan membuat video yang kemudian dibagikannya di Youtube tentang tips-tips keislaman dan tanggapannya mengenai fenomena sosial yang berkaitan dengan dakwah. Video Wirda Mansur sering mendapatkan respon positif dari para penontonnya.

Beberapa tayangan Wirda Mansur memotivasi para subscriber untuk membaca AlQur'an. Motivasi adalah sesuatu yang menggerakkan seseorang atau kelompok orang untuk melakukan atau tidak melakukan sesuatu. Motivasi dapat berasal dari individu yang bersangkutan maupun dari luar.

Berdasarkan paparan di atas, penulis memilih subscriber sebagai objek penelitian, karena berdasarkan pengamatan penulis bahwa program youtube channel Wirda Mansur mendapat komentar baik dan respon dari para penontonya dan banyak dari mereka yang termotivasi untuk membaca Al-Qur'an. Oleh karena itu, penulis ingin mengetahui apakah 
program youtube chanel Wirda Mansur mampu memberikan dampak positif bagi subscriber dalam hal beribada, salah satunya yaitu membaca Al-Qur'an. Hal ini selanjutnya penulis tuangkan dalam skripsi berjudul: "Pengaruh Intensitas Menonton Program Youtube Channel Wirda Mansur terhadap Motivasi Membaca Al-Qur'an Subscriber".

Tujuan Penelitian

Berdasarkan rumusan masalah di atas, maka tujuan penelitian ini adalah untuk:

1. Mengetahui dan memperoleh data tentang Youtube Chanel Wirda Mansur dalam memotivasi membaca Al-Qur'an.

2. Mengetahui dan memperoleh data tentang Intensitas Menonton Program Youtube Chanel Wirda Mansur.

3. Mengetahui dan memperoleh data tentang pengaruh Intensitas Menonton Program Youtube Chanel Wirda Mansur Terhadap Motivasi membaca Al-Qur'an Subscriber.

\section{B. Metodologi Penelitian}

\section{Pengertian Pengaruh}

Menurut Kamus Besar Bahasa Indonesia "Pengaruh adalah daya yang ada atau timbul dari sesuatu (orang atau benda) yang ikut membentuk watak, kepercayaan atau perbuatan seseorang." Sementara itu, Surakhmad menyatakan bahwa pengaruh adalah kekuatan yang muncul dari suatu benda atau orang dan juga gejala dalam yang dapat memberikan perubahan terhadap apa-apa yang ada di sekelilingnya. Jadi, dari pendapat-pendapat tersebut dapat disimpulkan bahwa pengaruh merupakan suatu daya atau kekuatan yang timbul dari sesuatu, baik itu orang maupun benda serta segala sesuatu yang ada di alam sehingga mempengaruhi apa-apa yang ada di sekitarnya.

Pengertian Intensitas

Intensitas berasal dari bahasa latin yaitu intention yang merupakan suatu ukuran kekuatan, keadaan tingkatan atau ukuran intens seseorang. Sedangkan dalam kamus besar bahasa Indonesia intensitas adalah keadaan tingkat atau ukuran intens. Intensitas adalah keadaan tingkatan dengan ukuran intensitasnya. Sedangkan istilah penggunaan diartikan sebagai hal mempergunakan sesuatu pemakaian, proses, cara, pembuatan, menggunakan sesuatu. Sedangkan penggunaan yaitu "proses atau cara menggunakan sesuatu".

Pengertian Menonton

Menonton merupakan suatu kegiatan menggunakan mata untuk memandang atau memperhatikan (Depdikbud, 1994 : 592). Sebagai salah satu aspek perhatian, menonton berusaha menggali informasi baik dari televisi maupun yang lainnya. Menonton berarti melakukan aktivitas atau menyaksikan sesuatu yang dilihat. Budiman (2002: vi) mengatakan bahwa menonton merupakan suatu tindakan tertentu dari adanya alat komunikasi yakni televisi.

\section{Komunikasi Massa}

Definisi komunikasi massa menurut Meletzke adalah memperlihatkan massa yang satu arah dan tidak langsung sebagai akibat dari penggunaan media massa, juga sifat pesannya yang terbuka untuk semua orang. Dalam definisi Meletzke, komunikasi massa diartikan sebagai setiap bentuk komunikasi yang menyampaikan pernyataan secara terbuka melalui media penyebaran teknis secara tidak langsung dan satu arah pada publik yang tersebar (Rakmat seperti yang dikutip dalam Komala). Istilah tersebar menunjukkan bahwa komunikan sebagai pihak penerima pesan tidak berada di suatu tempat, tetapi tersebar di berbagai tempat.

Media baru

Media baru (new media) merupakan alat atau sarana dalam menyampaikan pesan pada khalayak luas dengan teknologi digital atau disebut juga sebagai jaringan teknologi komunikasi dan informasi. Yang termasuk kategori media baru adalah internet, website, komputer multimedia. Tetapi internet lebih dikenal sebagai media baru, sebenarnya internet merupakan salah satu bentuk media baru, saat ini media baru sudah menjangkau hampir seluruh masyarakat dunia, media baru tersebut dapat dikatakan turut memberi andil yang besar pada berubahan struktur sosial masyarakat. Media baru memungkinkan orang untuk membuat, memodifikasi, dan berbagi dengan orang lain, dengan alat yang relatif sederhana yang sering dan gratis. 


\section{Youtube}

Youtube adalah sebuah portal website yang menyediakan layanan video sharing. User yang telah mendaftar bisa meng-upload video miliknya ke server Youtube agar dapat dilihat oleh khalayak internet diseluruh dunia. Video yang di upload biasanya merupakan video-video pribadi para penggunanya. Bukan itu saja, bahkan video klip artis Hollywood, Bollywood, dan video dari seluruh mancanegara bisa dicari disini. Video tersebut seperti kerusuhan Poso, acara Mamamia Show, dan lain-lain dapat ditemukan di Youtube.

Youtube memang belum lama berada di dunia internet karena baru didirikan pada tahun 2005 oleh 3 sekawan mantan karyawan PayPal yang merupakan perusahaan pembayaran transaksi melalui internet. Kemudian, pada tanggal 13 November 2006, Google membeli situs tersebut dengan harga 1,65 triliun Dolar. Youtube memang sangat populer. Fenomenanya dapat dikatakan mirip blog. Apabila blog merupakan buku harian online, Youtube adalah video harian online atau Vlog (Video Log). karena kepopulerannya itulah, beberapa website lokal Indonesia juga menyediakan layanan sejenis-tentunya bernuansa lokal.

\section{Pengertian Motivasi}

Motivasi merupakan istilah yang lebih umu digunakan untuk menggantikan tema "motif-motif" yang dalam bahasa inggris disebut dengan motive yang berasal dari kata motion, yang berarti gerakan atau sesuatu yang bergerak. Karena itu motivasi erat hubungannya dengan "gerak", yaitu gerakan yang dilakukan manusia atau disebut tingkah laku atau amaliyah. Motivasi dalam psikologi berarti rangsangan, dorongan, atau pembangkit tenaga bagi terjadinya tingkah laku. Dan motivasi dengan sendirinya lebih berarti menunjuk kepada seluruh proses gerakan diatas, termasuk situasi yang mendorong, dorongan yang timbul dalam diri individu.

\section{Pengertian Membaca}

Menurut Dalman. Membaca merupakan suatu kegiatan atau proses kognitif yang berupaya untuk menemukan berbagai informasi yang terdapat dalam tulisan. Membaca buku bukan hanya sekedar melihat kumpulan huruf yang telah membentuk kata, kalimat, paragraf dan wacana saja, tetapi membaca juga merupakan kegiatan memahami dan menginterpretasikan lambang/tanda/ tulisam yang bermakna sehingga pesan yang disampaikan penulis dapat diterima oleh pembaca.

Membaca memiliki arti penting bagi siapapun, dengan membaca seseorang dapat memperoleh informasi dan bahkan menambah pengetahuannya. Membaca merupakan salah satu di antara empat keterampilan berbahasa ( menyimak, berbicara, membaca dan menulis) yang penting untuk dipelajari dan dikuasai oleh setiap pemakai bahasa. Oleh karena itu, upaya untuk mengajaarkan cara membaca kepada anak sangat penting.

\section{Pengertian Al-Qur'an}

Dalam memahami definisi Al-Qur'an, ada dua pendekatan yang bisa digunakan, yaitu pendekatan secara lughawi (bahasa/etimologi) dan ishthilahy (terminologi). Secara bahasa, AlQur'an berasal dari kata qara'a, yaqra'u, qira;atan, wa quranan yang berarti menghimpun atau mengumpulkan. Jadi, Al-Qur'an didefinisikan sebagai bacaan atau kumpulan huruf-huruf yang terstruktur dengan rapi.

Sedangkan secara istilah, ada beberapa pendapat yang mendefinisikan Al-Qur'an. Para ulama Ushul Fiqh mendefinisikan Al-Qur'an sebagai kalam Allah yang diturunkan kepada Nabi Muhammad Saw secara bertahap melalui perantara Malaikat Jibril dan merupakan sebuah pahala dengan membacanya, yang diawali surat al-Fatihah dan diakhiri dengan surat an-Nas.

\section{Pengertian Subscriber}

Subscribers sederhananya adalah orang-orang yang berlangganan dengan blog kita. Karena mereka berlangganan dengan blog kita, subscribers akan tahu ketika blog kita di-update dengan posting atau artikel yang baru. Blog dengan dengan jumlah subsribers yang tinggi mencerminkan blog tersebut menawarkan informasi atau berita yang menarik, akurat dan juga bermutu. Dri pengertian ini dapat disimpulkan bahwa blog dengan jumlah subscribers yang tinggi akan sangat disukai oleh pengiklan atau pembeli Review. 
Subscribe dapat diterjemahkan sebagai langganan dalam bahasa Indonesia. Dalam Youtube, pengertian subscribe adalah fasilitas yang diberikan kepada para pengguna Youtube untuk berlangganan terhadap semua konten dalam channel tertentu. Meskipun arti subscribe banyak dikaitkan ke situs Youtube, pada dasarnya banyak situs lain juga memiliki fasilitas subscribe, misalnya Fanspage di Facebook, Website, atau Blog tertentu. Orang yang melakukan subscribe suatu channel untuk mendapatkan konten terbaru dari channel tersebut diistilahkan sebagai subscriber.

\section{Pembahasan dan Diskusi}

Intensitas berarti seluruh kegiatan dan usaha yang dilakukan agar diperoleh prestasi atau hasil memuaskan. Intensitas merupakan indikator yang pada saat seseorang melakukan sesuatu. Intensitas dalam kehidupan sehari-hari menggambarkan tingkat atau ukuran intensitas dalam penelitian ini merujuk pada intensitas menonton. Dalam intensitas terdapat indikator yaitu: motivasi, durasi kegiatan, frekuensi kegiatan, presentasi, arah sikap dan minat.

Motivasi ini menunjukkan keadaan seseorang untuk melakukan sesuatu untuk berbuat atau bertingkah laku secara terarah. Selanjutnya ada durasi kegiatan yakni seberapa sering seseorang menggunakan waktunya untuk melakukan kegiatan misalkan menonton youtube Wirda Mansur selama 1 jam, kurang dari lima menit atau sesuai dengan video yang ditayangkan. Selanjutnya frekuensi yaitu kecenderungan subscriber Wirda Mansur pada suatu video youtube Wirda Mansur secara terus menerus. Selanjutnya presentasi keinginan, cita-cita atau sasaran yang hendak dicapai dengan kegiatan yang dilakukan. Arah sikap menunjukkan bagaimana subscriber memberikan perhatian terhadap video Wirda Mansur. Bertingkah laku secara terarah suatu kesiapan pada diri sendiri seseorang untuk bertindak secara tertentu terhadap hal-hal.

Ramayulis menyatakan bahwa motivasi memiliki empat peran yaitu, pertama motivasi berfungsi sebagai pendorong manusia dalam berbuat sesuatu, menonton youtube Wirda Mansur mendorong para responden untuk membaca Al- Qur'an dan berusaha membaca Al- Qur'an dimanapun. Kedua, motivasi berfungsi untuk menentukan arah dan tujuan dengan adanya motivasi membaca Al-Qur'an ini para responden memiliki tujuan untuk mendapatkan kemuliaan dari membaca Al-Qur'an. Ketiga, motivasi berfungsi sebagai penyeleksi atas perbuatan baik atau buruk. Dan yang terakhir motivasi berfungsi sebagai penguji sikap manusia dalam beramal.

Setiap aktivitas yang dilakukan oleh manusia pada dasarnya dilandasi oleh adanya dorongan untuk melakukan sesuatu untuk mencapai tujuan dan terpenuhinya kebutuhan. Adanya daya pendorong ini disebut motivasi. Dalam intensitas menonton youtube Wirda Mansur terhadap motivasi membaca Al-Qur'an ini memiliki faktor yang mempengaruhi motivasi membaca. Faktor ini dibagi menjadi dua faktor yaitu faktor internal dan eksternal. Faktor internal meliputi faktor psikologis, seperti faktor kebiasaan dan kebutuhan. Semakin terbiasa untuk membaca Al-Qur'an maka motivasi yang didapat akan semakin besar, begitu juga dengan faktor kebutuhan, karena kebutuhan terkadang memaksa seseorang unruk membaca AlQur'an sehingga orang tersebut termotivasi untuk membaca. Faktor kedua yaitu eksternal dimana adanya peran orangtua dan lingkungan berupa lingkungan pertemanan ataupun sekolah.

Tabel 1. Correlations

\begin{tabular}{|c|c|c|c|}
\hline \multicolumn{4}{|c|}{ Correlations } \\
\hline & & $\begin{array}{l}\text { Intensitas_ } \\
\text { Menonton }\end{array}$ & $\begin{array}{c}\text { Motivasi_Membaca } \\
\text { Alquran }\end{array}$ \\
\hline \multirow[t]{3}{*}{ Intensitas_Menonton } & Pearson Correlation & 1 & $.376^{\prime \prime}$ \\
\hline & Sig. (2-tailed) & & .000 \\
\hline & $\mathrm{N}$ & 110 & 110 \\
\hline \multirow[t]{3}{*}{ Motivasi_Membaca_Alquran } & Pearson Correlation & $.376^{\prime \prime}$ & 1 \\
\hline & Sig. (2-tailed) & .000 & \\
\hline & $\mathrm{N}$ & 110 & 110 \\
\hline
\end{tabular}

JRKPI is licensed under Creative Commons Attribution-

NonCommercial-ShareAlike 4.0 International License. Komunikasi Penyiaran Islam 
Berdasarkan hasil perhitungan pada tabel korelasi, maka besarnya korelasi antara variabel intensitas menonton dengan motivasi membaca Al-Qur'an menunjukkan angka sebesar 0.376. angka tersebut menunjukkan adanya korelasi yang cukup dan searah. Artinya jika variabel intensitas menonton youtube besar, maka variabel motivasi membaca Al-Qur'an sucbscriber semakin besar pula. Menentukan signifikan hubungan dua variabel dapat dianalisis dengan ketentuan sebagai berikut: jika nilai probalibilitas $(\mathrm{sig})<0,05$, maka hubungan kadua variabel signifikan. Jika nilai probabilitas (sig)>0,05 maka hubungan kedua variabel tidak signifikan dengan kata lain tidak ada hubungan.

Tabel 2.

\begin{tabular}{|c|c|c|c|c|c|c|c|}
\hline Model & $\mathbf{R}$ & $\begin{array}{c}\mathbf{R} \\
\text { Square }\end{array}$ & $\begin{array}{c}\text { Adjusted } \\
\mathbf{R} \\
\text { Square }\end{array}$ & $\begin{array}{c}\text { Std. } \\
\text { Error Of } \\
\text { the } \\
\text { Estimate }\end{array}$ & Keputusan & $\begin{array}{c}\text { Derajat } \\
\text { Keeratan }\end{array}$ & $\begin{array}{c}\text { Koefisiensi } \\
\text { Determinasi }\end{array}$ \\
\hline 1 & .376 & .142 & .134 & 5.170 & Ho diterima & Cukup & $14.20 \%$ \\
\hline
\end{tabular}

Keputusan terlihat angka probabilitas hubungan antara variabel intensitas menonton youtube terhadap motivasi membaca Al-Qur'an sebesar 0,00 , dimana angka probabilitas (sig) 0,00<0,05 maka H0 ditolak dan H1 diterima, sedangkan jika sig (sig) 0,00>0,05, maka H0 diterima dan $\mathrm{H} 1$ ditolak. Ternyata berdasarkan hasil output bahwa nilai sig $0,00<0,05$ maka $\mathrm{H} 0$ ditolak, dan $\mathrm{H} 1$ diterima. Dengan kata lain artinya terdapat pengaruh antara intensitas menonton youtube chanel Wirda Mansur terhadap motivasi membaca Al- Qur'an subscriber secara signifikan.

Berdasarkan hasil perhitungan di atas, maka besarnya pengaruh variabel $\mathrm{X}$ (Intensitas Menonton Youtube Channel Wirda Mansur) terhadap variabel Y (Motivasi Membaca Al-Qur'an Subscriber) adalah sebesar 14,20\% intensitas menonton ini meliputi motivasi, durasi kegiatan, frekuensi kegiatan, presentasi, arah sikap dan minat. sedangkan sisanya sebesar $85,80 \%$ dipengaruhi oleh faktor lain diluar intensitas menonton.

\section{Kesimpulan}

Dari hasil penelitian ini dapat ditarik kesimpulan sebagai berikut:

1. Program youtube chanel Wirda Mansur memotivasi para subscriber untuk membaca AlQur'an. Banyak dari mereka yang meluangkan waktu untuk membaca Al-Qur'an. Berdasarkan tabel kusioner menyatakan bahwa menonton program youtube Wirda Mansur menumbuhkan motivasi sehingga banyak dari para subscriber ingin mempraktikan penjelasan Wirda Mansur dalam kehidupan sehari-hari.

2. Intensitas menonton di tunjukkan dari tabel kuisioner mengenai waktu pemakaian youtube dalam menonton, 63 orang $(57 \%)$ responden biasanya menonton youtube dengan intensitas waktu 1 jam dan menggunakan youtube lima kali dalam seminggu.

3. Pengaruh intensitas menonton terhadap membaca Al-Qur'an adalah sebesar 14,20\% sedangkan sisanya $85,80 \%$ dipengaruhi oleh faktor lain diluar intensitas menonton yang tidak diteliti oleh peneliti. 


\section{Daftar Pustaka}

[1] Eva, Nawiroh. 2016. Komunikasi Massa. Jakarta : Ghalia Indonesiaisep

[2] Elvinaro, Ardianto. 2004. Komunikasi Massa : Suatu Pengantar, Bandung : Simbiosa Rekatama Media.

[3] Saodah Wokdkk, 2005. Teori-teori Komunikasi, PTS Profesional

[4] Arifin, Bambang Syamsul. 2008. Psikologi Agama, Bandung : Pustaka Setia.

[5] Rianto, Anton. 2005. Born to Win : Kunci Sukses yang Tak Pernah Gagal, Jakarta : Gramedia Pustaka Utama.

[6] Tindaon, Yossi Abdian. 2012. Pengertian Pengaruh, "http://yosiabdiandaon.blogspot.com/2012/11 pengertian-pengaruh.html "

[7] Fitriyani, 2014. Pengaruh Penggunaan Teknologi Informasi, Keahlian, Pemakai dan Intensitas Pemakaian Terhadap Kualitas Informasi Akuntasi. Program Studi Akuntasi Universitas Bengkulu.

[8] Departemen Pendidikan Indonesia,2014. Kamus Besar Bahasa Indonesia: Jakarta Balai Pustaka.

[9] Julianti, Ike. 2014. Jurnal Pendidikan Fisika Vol 3 No. 1 Sa'adah, Fatkhiatus. 2018. Pengaruh Intensitas Menonton Program Acara Hafizh Indonesia di RCTI terhadap Motivasi Membaca Al-Qur'an. Fakultas Dakwah dan Komunikasi, Komunikasi Penyiaran Islam, UIN Walisongo Semarang.

[10] Romli, Khomsaril. 2016. Komunikasi Massa. Jakarta: Grasindo.

[11] Ramayulis, Psikologi Agama, Jakarta: Radar Jaya.s[ep?

[12] Meliyawati, 2016. Pemahaman Dasar Membaca. Yogyakarat: Deepublish Maunah, Binti. 2014. Psikologi Pendidikan. Yogyakarta: Lingkar Media. 